\title{
Animal models for aberrations of gonadotropin action
}

\author{
Hellevi Peltoketo $\cdot$ Fu-Ping Zhang • Susana B. Rulli
}

Published online: 12 April 2011

(C) The Author(s) 2011. This article is published with open access at Springerlink.com

\begin{abstract}
During the last two decades a large number of genetically modified mouse lines with altered gonadotropin action have been generated. These mouse lines fall into three categories: the lack-of-function mice, gain-of-function mice, and the mice generated by breeding the abovementioned lines with other disease model lines. The mouse strains lacking gonadotropin action have elucidated the necessity of the pituitary hormones in pubertal development and function of gonads, and revealed the processes from the original genetic defect to the pathological phenotype such as hypo- or hypergonadotropic hypogonadism. Conversely, the strains of the second group depict consequences of chronic gonadotropin action. The lines vary from those expressing constitutively active receptors and those secreting follicle-stimulating hormone (FSH) with slowly increasing amounts to those producing human choriogonadotropin (hCG), amount of which corresponds to 2000 -fold luteinizing hormone (LH)/hCG biological activity. Accordingly, the phenotypes diverge from mild anomalies and enhanced fertility to disrupted gametogen-
\end{abstract}

This work was supported by Wellcome Trust Grant 063552 (H.P.), the Academy of Finland (F.Z.), and the National Agency of Scientific and Technological Promotion grant PICT 2006:272 and CONICET of Argentina (S.B.R.).

H. Peltoketo $(\bowtie)$

Institute of Reproductive and Developmental Biology, Imperial College London,

DuCane Road,

London W12 0NN, UK

e-mail: h.peltoketo@ic.ac.uk

\section{F.-P. Zhang}

Department of Physiology, Institute of Biomedicine,

University of Turku,

Kiinamyllynkatu 10 ,

FIN-20520 Turku, Finland

\section{S. B. Rulli}

Instituto de Biología y Medicina Experimental-CONICET,

Vuelta de Obligado 2490 (1428),

Buenos Aires, Argentina esis, but eventually chronic, enhanced and non-pulsatile action of both FSH and LH leads to female and male infertility and/or hyper- and neoplasias in most of the gonadotropin gain-offunction mice. Elevated gonadotropin levels also alter the function of several extra-gonadal tissues either directly or indirectly via increased sex steroid production. These effects include promotion of tumorigenesis in tissues such as the pituitary, mammary and adrenal glands. Finally, the crossbreedings of the current mouse strains with other disease models are likely to uncover the contribution of gonadotropins in novel biological systems, as exemplified by the recent crossbreed of LHCG receptor deficient mice with Alzheimer disease mice.

Keywords Gonadotropin · Receptor · Ovary · Testis · Pituitary $\cdot$ Genetically modified

\section{Introduction}

Since the close connection between pituitary and gonads was revealed, luteinizing hormone (LH), folliclestimulating hormone (FSH) and their receptors have been intensively studied with the aim of understanding the function and malfunction of these organs. In this current review we concentrate on the experimental animal models that have elucidated the role of gonadotropins in normal gonadal function and, more importantly, what aberrations are caused by their abnormal actions in gonads and extragonadal tissues. Numerous mouse models with disrupted or enhanced gonadotropin signalling have been generated (Table 1). The phenotypes of these mice mimic several human conditions such as hypo- or hypergonadotropin hypogonadism, premature ovarian failure and ovarian hyperstimulation syndrome. The mouse strains and their crosses with other disease model lines are also useful when testing other hypotheses, such as gonadotropin action in tumorigenesis, bone metabolism and Alzheimer disease. 
Table 1 Mouse lines with disrupted or enhanced gonadotropin production and loss- and gain-of-function mutations of gonadotropins and their receptor

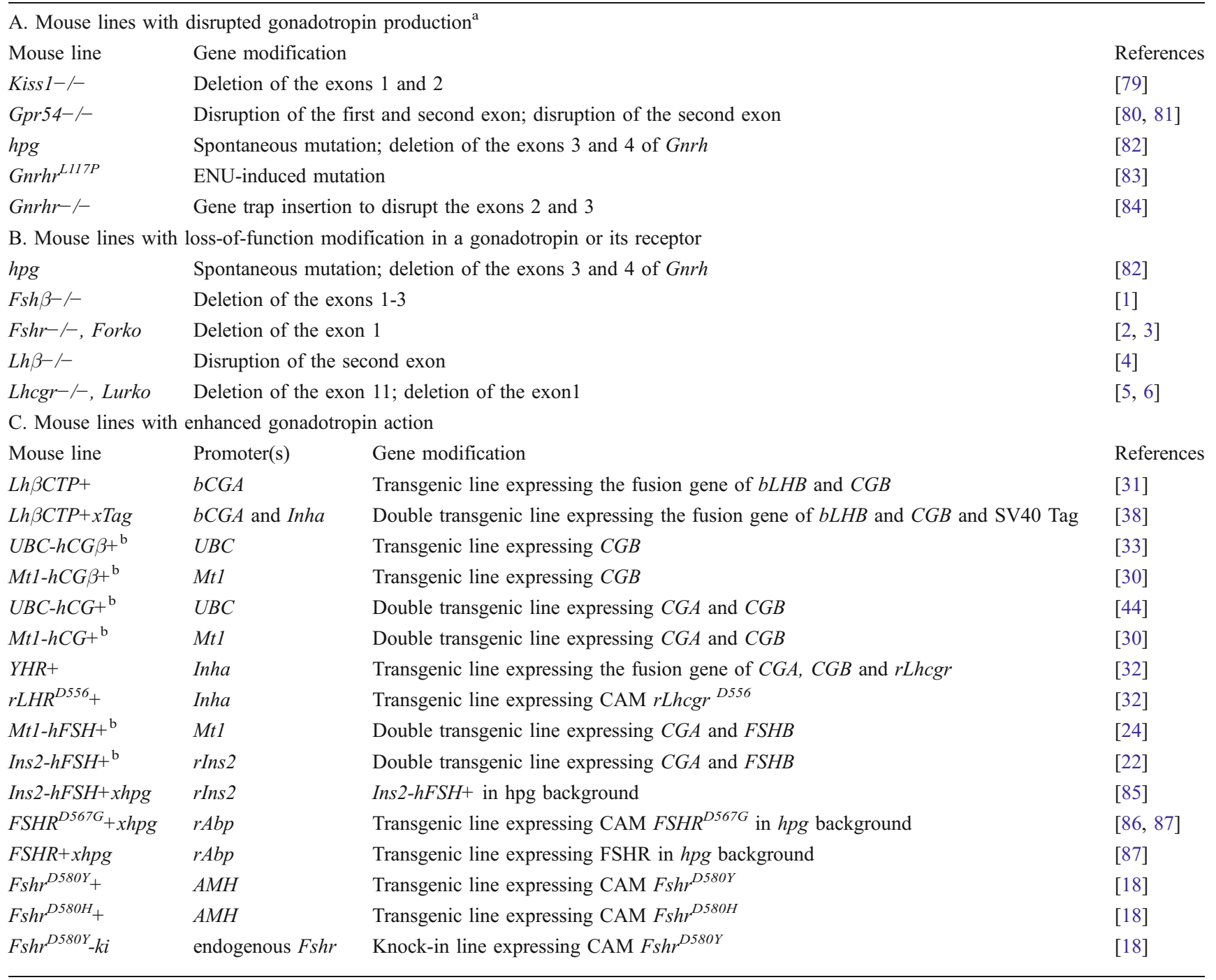

ENU N-ethyl-N-nitrosurea

$b$ bovine; $h$ human; $m$ mouse; $r$ rat; $A B P$ androgen binding protein; $A M H$ anti-Mullerian hormone; $C G A$ glycoprotein hormone-alpha polypepitide ( $\alpha$-subunit); $C G B$ beta; FSHB follicle stimulating hormone beta; $F$ shr follicle stimulating hormone; Gnrhr gonadotroping releasing hormone receptor; Gpr G protein-coupled receptor; hpg hypogonadal; Ins insulin; Kiss kiss-metastasis suppressor; LHB luteinizing hormone beta; Lhcgr luteinizing hormone/choriogonadotropin hormone receptor; Mt metallothionein; SV40 Simian virus 40; Tag T-antigen; UB ubiquitin; CAM constitutively active mutant

+ Depicts expression of a transgene in addition to endogenous genes

${ }^{a}$ The focus of the review being in the aberrations of gonadotropin action, the mice of the section A have been listed to demonstrate upstream events of the gonadotropin biosynthesis, but they have not been discussed except hpg mice

${ }^{\mathrm{b}}$ When two different mouse strains expressing the same gene but under different promoter have been generated, abbreviation of a promoter has been included into the strain name

\section{Experimental animal models for gonadotropin action in ovary}

The main target of gonadotropins in females is the ovary, maturation of which is triggered by LH and FSH at puberty. It is largely agreed and confirmed by animal models lacking FSH, LH or their receptors that the gonadotropins are not critical for the prenatal female uro-genital development.
Nevertheless, loss-of-function mutations in any of the gonadotropins or their receptors lead to delayed or interrupted progression of puberty, hypogonadism, primary amenorrhea, and consequently infertility [1-6]. In the absence of FSH or LH signalling, ovarian follicle growth does not progress beyond the preantral or early antral stage, respectively, leading to a deficit in estrogen and progesterone production and anovulation both in humans and 
rodents. Mice lacking gonadotropin function and their consistency with corresponding human ovarian conditions have been discussed in detail in several excellent review articles elsewhere [7-10]. Therefore we concentrate here in more detail on the role of gonadotropins in folliculogenesis, ovarian tumorigenesis and on the consequences of excess gonadotropin signalling, as demonstrated by the genetically manipulated animal models.

\subsection{Role of gonadotropins in the formation} and maintenance of the primordial follicle pool

The gonadotropin-dependence of ovarian function begins at puberty and involves the advanced follicular stages, but gonadotropins - and FSH in particular - may also affect the earlier stages starting the neonatal primordial folliculogenesis. FSH receptor ( $\left.F_{s} h r\right)$ is expressed in the neonatal mouse ovary and its expression increases significantly within the first three postnatal days together with serum FSH. In vitro FSH promotes mouse oocyte survival during the initial follicle formation by decreasing the apoptosis of the oocytes and by timing germline nest breakdown [11]. Similarly, the serum FSH peak coincides with the time of nest breakdown in developing human ovaries [12]. The early involvement of FSH in initial folliculogenesis is further emphasised by the data showing that anti-FSH treatment of hamster dams during pregnancy leads to reduced number of primordial follicles in pups [13] and that the amount of naked oocytes is substantially reduced in 2-day-old FSHR-deficient Forko mice. [14]. In addition, there are more growing, i.e. primary and secondary follicles in the newborn Forko mice than in wild-type animals, indicating disturbances in the timing of the initial follicular recruitment in the absence of FSH signalling.

In pubertal Forko females, the loss of primordial follicles is not accelerated compared to wild-type mice, suggesting that FSH action is not needed to maintain the primordial follicle pool. Conversely, FSH signalling linked to antiMüllerian hormone (AMH) action may be involved in removing the excess of primordial follicles after the initial formation of the pool $[14,15]$. In pubertal Forko [14] and adult hypogonadal (hpg) [16] mice that are lacking both LH and FSH, the number of primordial follicles is higher than in age-matched wild-type mice, and gonadotropin treatment of the hpg females causes an accelerated decrease of the follicular pool. In agreement, chronically elevated LH [17] and the constitutively active form of mFSHR, mFSHRD580H [18], lead to substantially accelerated loss of primordial follicles in the adult mice. Atresia of primordial follicles is apparently increased in the presence of excess gonadotropin action, since their augmented recruitment into the growing pool has not been detected $[17,18]$. Since the gonadotropin receptors are absent in primordial follicles
[19-21], the larger gonadotropin-responsive follicles may secrete a factor/factors promoting apoptosis of primordial follicles or inactivate any other/s supporting their survival.

2.2 Aberrant gonadotropin action during the gonadotropinresponsive, but not -dependent phase of follicular growth in mature mice

During follicular growth the earliest signs of FSHR and Fshr expression have been detected in the cuboidal granulosa cells of the primary follicles with a subsequent increase in more advanced follicles [19, 20]. The expression of ligand-responsive luteinizing/choriogonadotropin receptor (LHCGR) begins in the forming theca cell layer [21]. During this gonadotropin-responsive, but not yet dependent phase, the lack of gonadotropin signalling results in decreased number of secondary follicles $[14,16]$, but more importantly, they are susceptible to the excess of gonadotropin action, for instance caused by gain-offunction mutations in their receptors or exogenous gonadotropin production by endocrine tumors. Both chronically elevated LH [17] and FSH [22] as well as action of the constitutively active FSHR-D580H [18] lead to accelerated loss of small growing follicles and to abnormalities in the remaining follicles. The low number of the small growing follicles may thus be caused by the earlier described exhaustion of the resting follicle reserve and consequently decreased number of the recruited follicles. The enhanced gonadotropin action can also accelerate the growth of the remaining recruited follicles as it happens in mice expressing FSHR-D580H, $\mathrm{Fshr}^{\mathrm{D} 580 \mathrm{H}_{+}}$mice [18].

The collective data from the animal models suggest that during the early steps of folliculogenesis FSH is involved in the timing of the germline nest breakdown, protecting the perinatal primordial pool, and initiating the follicle recruitment (Table 2). Later on the protective role of FSH for the primordial pool is lost and conversely, the excess of FSH and LH indirectly accelerates the loss of primordial follicles. Both absent and increased FSH and LH action results in a reduced number of small growing follicles, and the augmented gonadotropin action leads to defects in the remaining follicles (see below). Therefore unbalanced gonadotropin signalling may be a factor leading to premature ovarian failure in women.

2.3 Aberrant gonadotropin action during the gonadotropindependent phase of follicular growth

In the absence of FSH and LH action, ovarian follicles develop until the preantral and early antral stage, respectively [1-6] (Table 2), thus verifying the need for gonadotropins in cyclic recruitment and pre-ovulatory growth of follicles, but not for the initial formation of 
Table 2 Influence of the aberrant gonadotropin action on the folliculogenesis. In each case the condition has been compared with the situation in a wild type mouse

\begin{tabular}{|c|c|c|c|c|c|}
\hline & $\begin{array}{l}\text { Loss of FSH } \\
\text { action }\end{array}$ & $\begin{array}{l}\text { Increased FSH } \\
\text { action }\end{array}$ & $\begin{array}{l}\text { Loss of LH } \\
\text { action }\end{array}$ & $\begin{array}{l}\text { Increased } \mathrm{LH} / \mathrm{hCG} \\
\text { action }\end{array}$ & References \\
\hline & \multicolumn{5}{|l|}{ Postnatal mouse } \\
\hline $\begin{array}{l}\text { Amount of naked oocytes; initial } \\
\text { primordial folliculogenesis }\end{array}$ & Decreased & Increased & dna & dna & {$[11,14]$} \\
\hline \multirow[t]{2}{*}{ The initial recruitment } & Increased & dna & dna & dna & [14] \\
\hline & \multicolumn{5}{|c|}{ Peripubertal and adult mouse } \\
\hline The pool of primordial follicles & Larger & Decreased & Larger & Decreased & {$[14,16-18]$} \\
\hline $\begin{array}{l}\text { Number of small follicles } \\
\text { (primary to preantral) }\end{array}$ & Decreased & Decreased & dna & Decreased & {$[14,16-18]$} \\
\hline Number of antral follicles & No antral follicles & $\begin{array}{l}\text { Increased in young } \\
\text { mature animals }\end{array}$ & Only early antral follicles & No effect & {$[1-6,17,18]$} \\
\hline Presence of hemorrhagic follicles & Not reported & Yes & Not reported & Yes & {$[18,24,30-32]$} \\
\hline
\end{tabular}

dna data not available

granulosa or thecal cell layers. Arrest of follicle development results in small ovarian size, decreased production of inhibins [3] and estradiol [4-6, 23] as well as missing ovulation and luteinisation, leading to decreased progesterone production $[1,4,6,23]$. The insufficient production of ovarian hormones causes uterine atrophy and disordered estrous cycles, and the concomitant lack of negative feedback from ovary to hypothalamic-pituitary axis results in chronic secretion of both FSH and LH, when either of the gonadotropin receptor is missing [1-6]. Increased and non-pulsatile secretion of one gonadotropin, however, cannot compensate for the lack of the other.

Chronically increased FSH action causes serious abnormalities in ovarian function that correlates to the level of the excess of FSH signalling. The Ins $2-h F S H+$ line represents the situation, in which the serum concentration of FSH gradually rises during the aging of the mice. The augmented FSH levels in Ins2-hFSH+ mice exert a biphasic effect on fecundity, first seen as increased litter size but later as premature infertility [22]. Similarly, young $F s h r^{D 580 H_{+}}$mice expressing a modest level of constitutively active receptor show increased fertility, but with aging or upon further increased expression of $F s h r^{D 580 H}$ their fertility is severely compromised [18]. Expression of Cyp19 is increased in the Fshr ${ }^{D 580 H_{+}}$ovaries causing increased estradiol production and consequently high prolactin secretion. These apparent changes cause perturbation of the LH surge leading to appearance of luteinized-but unruptured follicles (Fig. 1a-b). In addition, the hormonal imbalance disrupts the estrous cycle, and alters the vaginal epithelium and its capacity to support implantation. Also other structural alterations are common in the Fshr ${ }^{D 580 H_{+}}$ovaries; at the age of 2 to 3 months they are hyperstimulated, but contain numerous hemorrhagic follicles of poor quality (Fig. 1a-b); periodic acid Schiff-positive cell clusters with foamy and multinuclear cells are evident in ageing mice (Fig. 1c-f); and in the most affected animals the surface epithelium is hyperplastic [18]. In addition, germ-cell tumors, teratomas, are apparent in a fraction of the $F s h r^{D^{580 H}}$ ovaries [18]. Finally, the supra-physiological amount of circulating FSH in $\mathrm{Mt1}-\mathrm{FSH}+$ mice leads to quick deterioration of follicle function and infertility [24]. Folliculogenesis initiates normally in these mice, but by 6-7 weeks of age the ovaries are packed with massive fluid-filled and hemorrhagic cysts, and in 8-month old mice no late-stage follicles or corpora lutea are seen any more [24].

FSH acts as a determining factor in the cyclic recruitment of follicles and as a survival factor for antral follicles to rescue them from atresia [25]. The current mouse strains show that excess FSH action can also overrule quantity and quality control mechanisms in selection of dominant follicles such as those regulated by AMH [26]. FSH regulates the proliferation of granulosa cells in the growing follicles, which function is reflected by decreased cyclin D2 expression in Forko mice [14] and increased Ki67 expression in $F s h r^{D 580 H_{+}}$mice [18]. A notably higher number of primary and secondary follicles are Ki67-positive in $\mathrm{Fshr}^{\mathrm{DS} 80 \mathrm{H}_{+}}$than in wild-type mice, thus apparently leading to the accelerated growth of the follicles and explaining the ovarian hyperstimulation detected in young adult $F$ shr ${ }^{D 580 H_{+}}$females (Fig. 1a-b). These mice have an increased number of large growing follicles, several of them being hemorrhagic, and the progression into large follicles continues even though the ovaries show premature ageing and accelerated loss of small follicles (Fig. 1c-e) [18]. In agreement, the amount of corpora lutea and uterine implantation are significantly higher in young Ins2-hFSH+ than wild-type females leading to larger litters [22]. When 
Fig. 1 An example of ovaries affected by chronically elevated gonadotropin action. Micrographs of ovarian sections from wild-type (wt) mice (a, c), mice expressing constitutively active FSHR $\left(F s h r^{D 580 H_{+}}\right)(\mathbf{b}, \mathbf{d}-\mathbf{e})$ and mice expressing hCG $\beta$-subunit $(U B C-h C G \beta+)$ (f). Arrowheads indicate oocytes trapped inside lutenized follicles in the hyperstimulated $F s h r^{D 580 H_{+}}$ovary (b); arrows indicate multinuclear and foamy cell clusters in the ovaries of ageing $F$ shr ${ }^{D 580 H}+$ mice (d, e). $U B C-h C G \beta+$ females have heavily luteinized ovaries (asterisk) by the age of $\mathbf{3}$ months (f). $A F$ antral follicle; $S F$ secondary follicle; $H$ haemorrhage; $C L$ corpus luteum; $m o$ month. Scale bar $500 \mu \mathrm{m}$
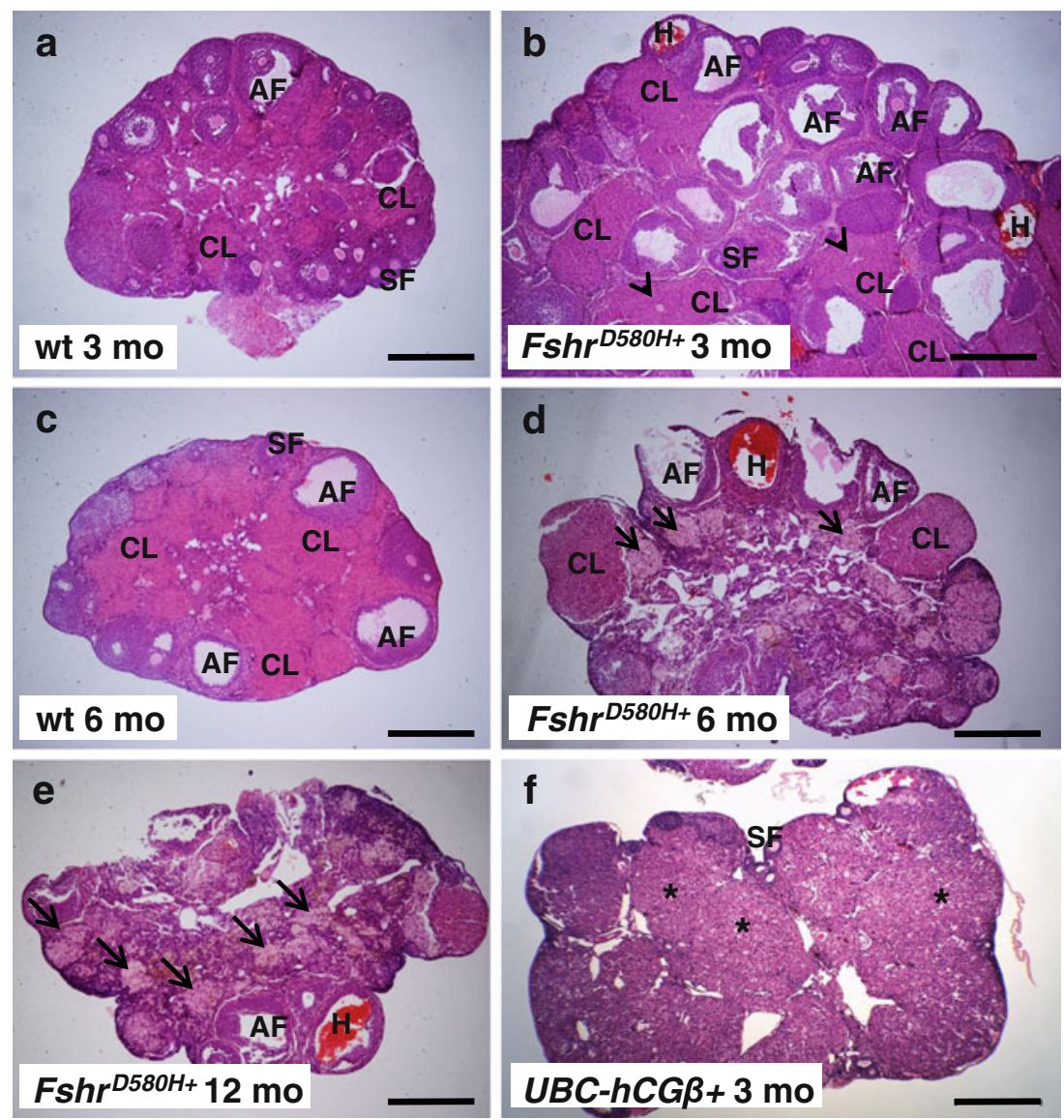

Ins $2-h F S H+$ females become older their litter sizes decrease due to increased reabsorption of embryos, also implying poor quality of ovulated and fertilized oocytes. It is generally understood that the leading follicles grow faster than the rest of the cohort producing higher amounts of estradiol and inhibins than the others [25]. Ins2-hFSH+ and Fshr ${ }^{D 580 H_{+}}$ females, however, escape the negative feedback of estrogens and inhibins and its influence on FSH secretion, and thus also the remaining antral follicles besides the leading ones continue to grow, bringing about the phenotype of hyperstimulated ovaries. It mimics the ethiology of the human pregnancy-dependent ovarian hyperstimulation syndrome that is caused by activation of a mutated ligand-nonspecific FSHR by hCG [27].

While FSH signalling is critical for the follicular development from preantral to early antral phase, LH signalling is essential for the further steps to pre-ovulatory stage and ovulation, and it cannot be compensated for by high-dose FSH [28]. The under-development of the reproductive organs and female infertility are due to low estrogen production and anovulation in Lhcgr deficient Lurko mice. Accordingly they demonstrate a dramatic decrease in the ovarian mRNAs for steroidogenic proteins, steroidogenic acute regulatory protein (StAR), cytochrome
P450-side-chain cleavage (P450-scc), and P450-aromatase with being practically undetectable $[6,28]$. Lurko mice also lack the LH stimulus that is needed to express sufficiently and temporally several genes associated with ovulation, such as $P r, C o x-2, T_{s}$-6, amphiregulin, epiregulin and $\beta$ cellulin [28]. Whereas high doses of FSH can induce ovulation in hypophysectomised rodents [29], this does not occur in Lurko mice indicating that Lhcgr expression, by unknown mechanism, may be needed for the FSH-induced ovulation. Whether LHCGR/FSHR dimerisation is necessary for this event remains to be evaluated.

Excessive LH signalling also leads to female infertility due to abnormal follicle maturation and lack of ovulation. Depending on amount of excessive gonadotropin stimulation, transgenic female mice develop progressively failing ovaries. The young low-copy $M t 1-h C G+$ females produce offspring similar to wild-type mice, but the former become infertile by 6-7 months for unknown reasons [30]. Folliculogenesis in high-copy $M t 1-h C G+$ females, instead, disrupts before ovulation and the ovaries turn largely hemorrhagic and cystic, the mice thus being infertile through their life. In young $L h \beta C T P+$ [31], YHR+ [32], and $U B C-h C G \beta+$ [33] mice (for details see Table 1), folliculogenesis progresses until luteinization, but due to 
constant $\mathrm{LH} / \mathrm{hCG}$ stimulus rather than a gonadotropin surge, oocytes are found trapped inside luteinized follicles and mice are infertile. At the age of 1 month estradiol production is increased in $U B C-h C G \beta+$ mice [33], but as the females ages, intensive luteinization takes place (Fig. 1f), and the elevated estradiol concentration is replaced by high progesterone and testosterone secretion [33]. In LhßCTP+ [31] and YHR+ [32] females estradiol production remains elevated aside increased progesterone production, leading to hypertrophic uterine growth. Moreover, very high hCG production - comparable to 2000 -fold biological LH/CG activity-in $U B C-h C G+$ females causes formation of bilateral teratomas.

In $L H \beta C T P$ and $Y H R+$ strains LH signalling is prematurely initiated, and evident precocious puberty occurs in female mice reflected by early vaginal opening, advanced follicle growth and an enlarged uterus [32, 34]. The results imply that prepubertally excessive LH action is able to trigger increased estradiol production despite reduced FSH concentration. While the different gonadotropin-related mouse models in general are good phenocopies for several human disorders, in case of gonadotropin-related precocious puberty there are distinct dissimilarities between the species. Women carrying the same gain-of-mutations in LHCGR that causes testotoxicosis in their male relatives do not suffer from any obvious endocrine problems such as premature puberty, hyperandrogenism or infertility, contrasting the LH $\beta C T P$ and $Y H R+$ females. Both quantitative and qualitative dissimilarities in hormone action may explain the differences between the species; excessive LH signalling in $L H \beta C T P$ and $Y H R+$ females may be more robust than that in women carrying constitutively active LHCGR, and it is thus able to reach the threshold needed for the initiation of puberty. Moreover constitutively active forms of human LHCGR can be further stimulated by LH to trigger an LH surge effect and enable ovulation, while LH $\beta C T P$ and $Y H R+$ female mice are anovulatory due to the constant activation of the receptor that cannot mimic the LH surge. Contrary to the mice, excess LH action in girls may neither be able to compensate undersupply of FSH needed for human follicle development and progress of puberty. Finally, the explanation may be that $L H C G R$ expression in human ovary does not begin until the onset of FSH secretion at the normal age of puberty.

\subsection{Potential role of gonadotropins in ovarian tumorigenesis}

The potential role of gonadotropins in initiation and/or progression of ovarian tumors has been discussed for decades (for a recent review see [35], for example). Intriguingly, in genetically modified animals both excess and lack of gonadotropin action have been linked with tumorigenesis including germ cell, sex-cord and surface epithelial tumors. Firstly, strong stimulation of LH signalling causes development of mature teratomas bilaterally in all $U B C-h C G+$ females [36], while unilateral teratomas have been detected in about $20 \%$ of $F s h r^{D 580 H}$ female mice, with some of the tumors being immature [18]. High gonadotropin stimulation - both FSH and LH-of granulosa cells may thus interfere with oocyte maturation and trigger parthogenetic activation of oocytes. Secondly, $L H \beta C T P+$ females develop granulosa and theca cell tumors with ageing, but only in a genetically predisposed background and when the LH surge is not taking place $[31,34,37]$. Together with the finding that such tumors do not develop in $U B C-h C G+$ mice [36], it suggests that excessive stimulation of LHCGR may be a promoting rather than an initiating factor in this response. Constant expression of $L H \beta C T P$ also accelerates development of the SV40 T-antigen-initiated granulosa cell tumors [38] further implying a role for $\mathrm{LH} / \mathrm{hCG}$ in ovarian sex-cord cell tumorigenesis.

The role of FSH in promoting somatic cell tumors is more complicated. Firstly, most Forko mice older than a year develop both sex-cord and epithelial ovarian tumors including granulosa cell tumors and serous papillary epithelial adenomas $[39,40]$. Aging $F s h r^{D 580 H_{+}}$mice also develop ovarian surface epithelial hyperplasia [18] and the presence of FSH accelerates the formation of granulosa cell tumors in inhibin- $\alpha$-deficient mice [24] suggesting, that FSH signalling can both suppress and support hyper- and metaplastic growth of several cell types directly or indirectly. Interestingly, according to a recent finding the expression of FSHR is promoted in endothelial cells at the borderline area of different kinds of human malignant tumors [41] prompting the question about a possible role of FSH in the progression and invasion of cancer in general.

\section{Experimental animal models for gonadotropin action in testis and male accessory glands}

Similarly to ovarian function in women the gonadotropins, particularly LH, play a key role in the differentiation and maturation of testis in men. Mutations in $L H \beta$ and $L H C G R$ causes various types of pathological conditions in men including lack of or delayed puberty, absence of secondary sexual characteristics and arrested spermatogenesis, while $F S H \beta$ and FSHR mutations lead to impaired testicular function but not necessarily to infertility [7]. During the last 15 years several genetically modified animal models for aberrant gonadotropin action have been generated and they have greatly increased knowledge of the molecular pathogenesis of gonadotropin-related conditions. 
3.1 Aberrations in testis and male accessory glands of $\mathrm{LH} \beta$ and LHCGR deficient mice

As with in females, LH action in males is essentially needed first time during the pubertal development. The testes of newborn LHCGR deficient, Lurko males are similar in size and microscopic appearance to those of wild type littermates, and their intra-abdominal location adjacent to the urinary bladder is unchanged [5], indicating that LH signalling is not needed for prenatal testicular development. Adult LH $\beta$ deficient, $L h \beta-/-$ and Lurko males instead are infertile, with their testis weight being about $25 \%$ of that in wild-type age-matched littermates [4-6]. The accessory glands are also undersized consistent with decreased circulating $(<10 \%)$ and intra-testicular $(<5 \%)$ testosterone levels. Testicular histological analysis shows spermatogenesis, which is blocked at the round spermatid stage [5,6], and insignificant interstitium with very few, small-sized Leydig cells [4-6]. Gene expression analyses have confirmed an increase in the fetal Leydig cell marker, thrombospondin-2, and reduction in many of the steroidogenic pathway enzymes. In addition, levels of the androgen precursor, androstenedione, are enhanced, indicating the presence of mostly fetal and immature Leydig cells in the $L h \beta-/-$ testes [4].

Testosterone replacement therapy of Lurko males can partially restore the phenotypes and improve spermatogenesis beyond the round spermatid stage, but the mice remain sub-fertile. Fewer than $10 \%$ of all breedings have resulted in pregnancy, and only two of 13 mice $(15 \%)$ tested have been fertile. The reasons for this include poor accessory sex gland function and impaired sexual behaviour, as well as inflammation in the epididymis and prostate in many testosterone-treated Lurko mice [42]. Surprisingly, by the age of 12 months the arrested spermatogenesis in untreated Lurko testes has appeared to be progressed further, until elongated spermatids at late stages 13-16, indicating that spermatogenesis can be completed even without LH signalling and high intratesticular testosterone concentration (Fig. 2). Late-onset recovery of spermatogenesis in Lurko mice suggests that only total abolition of testicular androgen action may result in consistent azoospermia necessary for effective male contraception [5].

Recently, transgenic mice co-expressing bindingdeficient and signalling-deficient forms of LHCGR in

Fig. 2 Representative light micrographs of testicular sections from homozygous Lurko $(-/-)$ and wild type control $(+/+)$ mice. Samples were taken from Lurko (-/-) at the ages of 2 months (a and b) and 12 months (c and $\mathbf{d})$ and from control wild-type mice at 12 months (e and $\mathbf{f})$. b, $\mathbf{d}$, and $\mathbf{f}$ are views of $\mathbf{a}, \mathbf{c}$, and $\mathbf{e}$ at higher magnification. Arrows and arrowheads indicate round spermatids and elongated spermatids, respectively. mo month. The figure is a modification from the original figure presented in [78]
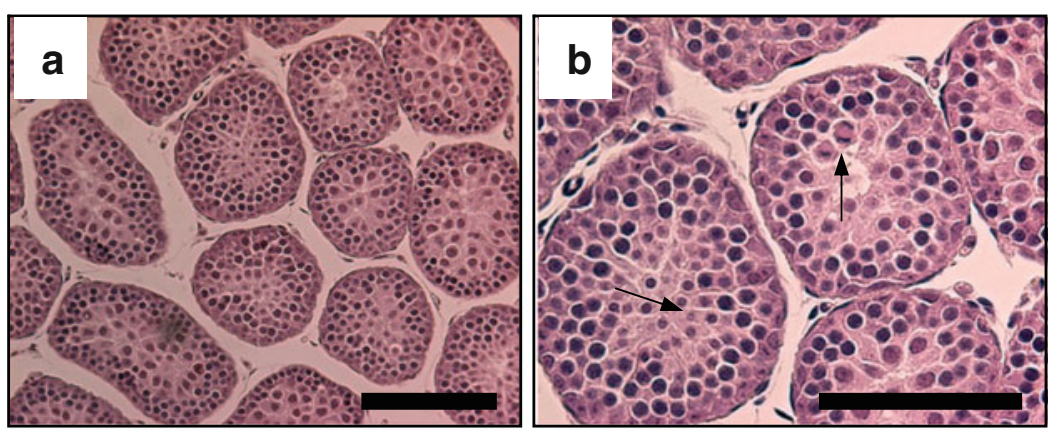

$(-/-), 2$ mo
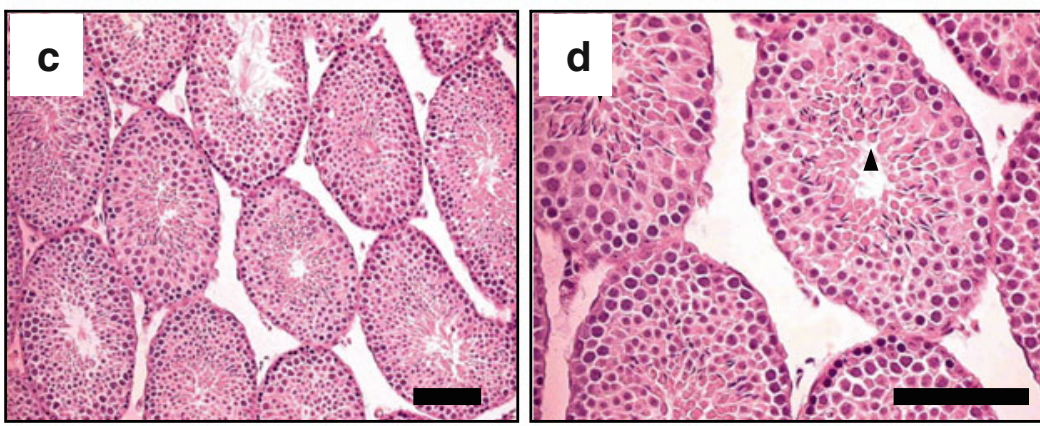

$(-/-), 12$ mo
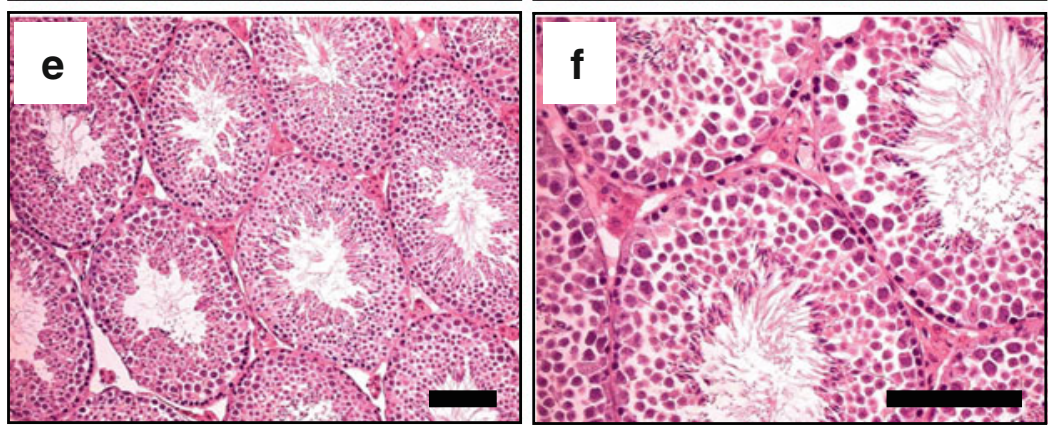

$(+/+), 12 \mathrm{mo}$

bar $=50 \mathrm{~mm}$ 
Lurko background have been generated [43]. The male mice demonstrate close to complete restoration of $\mathrm{LH}$ action; testes of the mice descend normally to the scrotum, are normal in weight and size, and accessory sex organs are fully developed, all consistent with serum testosterone concentration reset to the wild-type range. Testicular histology also shows full spermatogenesis and normalsized Leydig cells. Males are fertile and sire similar numbers of pups as wild type males. The study demonstrates that normal LH actions can be achieved via dimerization of binding-deficient and signalling-deficient LHCGR in the absence of functional wild-type receptor [43]. It will be intriguing to see whether LHCGR transactivation is sufficient to maintain the same complex action of LH needed in the maintenance of female fertility.

\subsection{Aberrations in male $\mathrm{LH} / \mathrm{hCG} / \mathrm{YHR}$ over-expressing mice}

Several experimental animal models demonstrate the influence of enhanced LH signalling on the function of testis; the stronger the LH signalling is, the more severe the consequences are. UBC- $h C G \beta+$ and $Y H R+$ males are fertile and show only mild anomalies, in agreement with their moderate increase in bioactive hCG and LH signalling $[32,44]$. Though the mice have smaller testes than wildtype mice, spermatogenesis is completed and quality of sperm is normal. Similarly, the subunit $\mathrm{C} \alpha$ overproducing males demonstrate no obvious abnormalities, in keeping with the necessity of $\alpha / \beta$ dimerization for the biological activity of hCG. In contrast, the double transgenic $U B C$ $h C G+$ males expressing both $\alpha$ and $\beta$ subunits are infertile and their reproductive organs show severe alterations with small testes, enlarged seminal vesicles and prostate, dilated vasa deferentia and urinary bladder, as well as kidney defects in adulthood due to high testosterone production [44]. Prepubertal $U B C-h C G+$ males have large Leydig cell nodules, classified as adenomas that reach their maximum size at the age of 10 days and that regress between the ages of 21 and 60 days [45]. The expression pattern of fetal and adult Leydig cell markers indicates that the adenomas in the $U B C-h C G+$ males are derived from fetal Leydig cells, and these adenomatous fetal Leydig cells regress according to their normal lifespan, explaining the disappearance and absence of Leydig cell adenomas in adult age [45]. Moreover, the adult Leydig cells appear to be resistant to hCG/LH-stimulated formation of adenomas. Surprisingly, neither $Y H R+$ or $U B C-h C G+$ males show any signs of precocious puberty despite prematurely increased circulating testosterone $[32,45]$. This suggests that the onset of pubertal maturation in mice is already at its minimum in wild-type males, or that it is triggered by some other unknown factor.
3.3 Aberrations in testis and male accessory glands in FSH $\beta$ and FSHR deficient mice

FSH signalling is not as crucial for testicular function as $\mathrm{LH}$ is. Both FSH $\beta$ and FSHR deficient $(F \operatorname{sh} \beta-/-$ and Forko) mice are fertile despite the reduced testis size and seminiferous tubule volume [1-3]. Stereological analyses have confirmed around $30 \%$ reduction in Sertoli cell number and germ cell carrying capacity, consistent with reduced testis size in $F \operatorname{sh} \beta-/-$ mice [46, 47]. The number of Leydig cells and concentration of intratesticular testosterone increase slowly in Forko mice after puberty and are significantly reduced in adult animals [48]. This is associated with reduced levels of mRNA encoding P450scc, 3ß-hydroxysteroid dehydrogenase type VI, and StAR in Forko mice [48]. The accessory glands of the $F \operatorname{sh} \beta-/-$ mice are however normal, verifying the presence of adequate number of Leydig cells and serum testosterone concentration [1].

Spermatogenesis is completed and many tubules contain mature spermatozoa in Fsh $\beta-/-$ and Forko testes though partial spermatogenic failure has been observed [1-3]. Flow cytometric evaluation of germ cells has revealed a significant increase in the percentage of spermatogonial and non-germ cells in Forko mice, with substantially less elongated spermatids than their wild-type littermates. Defects in sperm head shape, chromatin condensation, and chromatin remodelling are also apparent $[49,50]$, thus leading to decreased sperm viability and motility, and consequently reduced fertility and a delay in the first mating [49].

\subsection{Aberrations in male FSH over-expressing mice}

Overexpression of FSH, such as in Mt1-hFSH+ mice, results in normal testicular development and lack of any obvious histological defects in adult testes [24]. The seminiferous tubules are healthy and intact, spermatozoa are abundant in the lumen, and the number of Leydig cells in the interstitial spaces is normal [24]. In addition, Mt1$\mathrm{FSH}+$ mice show enlarged seminal vesicles secondary to elevated serum testosterone levels. Nevertheless, the Mt1$\mathrm{FSH}+$ mice are infertile that is thus caused by behavioural rather than structural defects. In other mouse lines with enhanced FSH signalling, obvious perturbations in testicular function have not been reported.

Interestingly, the testes of Ins2-FSH+xhpg mice (for details, see Table 1) are up to 5-fold larger than those of $h p g$ only mice depending on FSH concentration. Only the Ins 2-FSH+xhpg males having serum FSH level higher than $1 \mathrm{IU} /$ liter show larger testes than $h p g$-only mice, indicating a physiological FSH threshold for the testicular response [51, 52]. Enlarged Ins2-FSH+xhpg testes contain round 
spermatids and a sparse number of elongated spermatids. Hence without LH-induced testosterone production, FSH action alone on Sertoli cells may facilitate the completion of meiosis and minimal initiation, but not completion of spermiogenesis. Furthermore, transgenic $F S H$ expression in hpg mice restores the number of Sertoli cells to the same level as in mature wild-type mice in a dose-dependent fashion, despite the absence of LH and persistently low intratesticular testosterone [52]. Altogether, FSH alone can stimulate the complete development of Sertoli cells but spermatogenesis does not occur without LH signalling [52].

\section{Consequences of excessive gonadotropin action on pituitary function}

The aberrant action of gonadotropins leads to many endocrine disorders, both in humans and experimental animal models $[7,53]$. The intensity and complexity of the pathology are affected by the amount of hormones produced, duration of the stimulus, and the period in which the hormone stimulus is active. Transgenic mice with overproduction of $\mathrm{hCG} / \mathrm{LH}$, such as $L H \beta C T P+, U B C$ $h C G \beta+$ and $U B C-h C G+$ mice have revealed novel phenotypes in pituitary function, both in males and females [31, 33, 36, 44, 54-56]. Female mice bearing constitutively active mutations of the FSHR, Fshr ${ }^{\mathrm{DS}^{20 H}+}$ mice, also demonstrate distinct alterations in their pituitary function [18]. However, in all of the mouse strains the pituitary disorders are apparently secondary to increased gonadal hormone production.

The $U B C-h C G \beta+$ mice produce moderate amounts of $\mathrm{hCG} \beta$ subunit in a large number of tissues [33, 44], and the transgenic $\mathrm{hCG} \beta$-subunit associates with the endogenously expressed common $\alpha$-subunit to form bioactive hCG. The dimerization results in around 40-fold increase in $\mathrm{LH} / \mathrm{hCG}$ bioactivity in females [33], but only 3 - to 4 -fold increase in males [44]. The amount of endogenous $\alpha$-subunit limits the dimerization process of hCG that is obligatory for hormonal activity, the individual hCG subunits being devoid of bioactivity [57]. The difference between male and female hCG secretion may be due to differences in feedback regulation of the common $\alpha$-subunit expression by gonadal hormones [58]. Accordingly, $U B C-h C G \beta+$ females produce high amounts of estradiol, testosterone and progesterone from the early stages of sexual maturation [33].

One of the most intriguing phenotypes observed in the $U B C-h C G \beta+$ mice is the presence of lactotrope hyperplasia followed by development of prolactinomas in adult female mice $[33,55]$. This is strictly dependent on the ovarian function, since ovariectomy prevents the hyperprolactinemia and pituitary adenoma formation, despite persistently elevated serum hCG concentration. Similarly, the $F_{s} h r^{D 580 H_{+}}$ females exhibit increased serum concentration of estradiol and prolactin in association with adenomatous pituitary growth [18]. The constantly enhanced estradiol stimulation apparently causes the development of prolactinomas in $F s h r^{D 580 H}+$ females [18], whereas in $U B C-h C G \beta+$ mice ovarian estradiol production is elevated only temporarily before puberty [44]. The well-known influence of estradiol in the induction of pituitary adenomas [59] is therefore insufficient to explain the tumor pathogenesis in the latter mice. Instead, ovarian progesterone production remains high in $U B C-h C G \beta+$ females and in agreement with this, excess progesterone has been shown to promote the growth of primary mouse pituitary cells and rat somatolactotrope GH3 cells in the presence of physiological levels of estradiol [55]. Evidence for the involvement of progesterone is also obtained in vivo; antiprogestin mifepristone treatment inhibits pituitary tumor growth in $U B C-h C G \beta+$ females, and combined estradiol/progesterone treatment is more effective than estrogen treatment alone in inducing tumor growth after gonadectomy. The molecular mechanism of progestininduced growth of rodent pituitary cells involves the activation of the tumorigenic cyclin D1/cyclin-dependent kinase 4/retinoblastoma protein/transcription factor E2F1 signaling cascade [55], which has profound similarities with development of human pituitary adenomas [60]. The importance of these studies lies in the potential role of the hCG overproducing mouse model for addressing the development and treatment of pituitary adenomas in individuals with high gonadotropin levels (such as after menopause).

The double transgenic $U B C-h C G+$ mouse model that coexpresses both the common $\alpha$ - and hCG $\beta$-subunit transgenes produces highly elevated levels of dimeric hCG, reaching as high as 2000 -fold increase in $\mathrm{LH} / \mathrm{hCG}$ biological activity $[36,44]$. In $U B C-h C G+$ males the concentration of androgens is elevated from the early development and they induce a profound and persistent malfunction of the neuroendocrine feedback control [56]. This results in accelerated hypothalamic GnRH pulse release and concomitant suppression of the pituitary-gonadal axis, which can be re-established only by blocking the androgen action perinatally [56]. These findings suggest the existence of a critical window in perinatal life, when androgens determine the level of activation of the male hypothalamic-pituitary axis, and that high androgen concentration can persistently shut down the pituitary gonadotrope differentiation and gonadotropin synthesis and secretion. A direct testosterone-dependent stimulation of the hypothalamic aromatase expression has been demonstrated in $U B C-h C G+$ males, and hence hypothalamic aromatization of gonad-derived androgens to estradiol may play a key role. These findings strongly suggest that androgen excess is able to disrupt the developmental programming of the male hypothalamicpituitary-gonadal axis in mice [56]. 


\section{Impact of abnormal gonadotropin action on tissues outside the hypothalamic-pituitary-gonadal-axis}

Gonadotropins, in particular LH, are suggested to exert their effect via receptor binding on several extra-gonadal tissues. In addition, imbalanced gonadal hormone production caused by disturbed gonadotropin action affects the function of several tissues outside the hypothalamic-pituitary-gonadal axis. The mammary gland is an obvious target for the enhanced hormone action. Increased LH and FSH signalling may indeed cause hyperplastic or even malignant growth of the gland directly or due to the enhanced ovarian estradiol, prolactin and/or progesterone production. Fshr ${ }^{D 580 H_{+}}$ females display typical pseudopregnant appearance with augmented lobulo-alveolar growth, but malignant transformation has not been detected in this strain [18]. Mammary gland development is also accelerated in $L H \beta C T P+$ mice, with young virgin mice having glands typical of late pregnancy [61]. During chronic LH signalling, mammary gland hyperplasia advances spontaneously to tumors, mainly in the form of intraepithelial neoplasias. They can further progress to invasive carcinomas, if the mice are treated with the mammary gland carcinogen, 7,12-dimethylbenz(a)antrharcene [37, 61]. The aging $U B C-h C G \beta+$ females show mammary epithelial hyperplasia and cytoplasm vacuolization that advances to adenocarcinoma with papillary or nondifferentiated pattern [33]. The tumors are estrogen and progesterone receptor-negative, but instead resemble those induced by activated wnt $/ \beta$-catenin pathway. Accordingly, they show increased $\beta$-catenin stabilization via up-regulation of $w n t 5 b$ and $w n t 7 b$ that is independent of the changes in ovarian steroidogenesis [62]. The capability of $\mathrm{LH} / \mathrm{hCG}$ to modulate directly the wnt/ $\beta$-catenin pathway in mammary epithelial cells may explain the severity of the consequences of its chronic and elevated action compared to $\mathrm{FSH}$, the receptor of which is not expressed in the mammary gland.

During a woman's reproductive years, FSH has wellestablished osteoprotective functions via enhanced estrogen production. In agreement with this, the ageing Forko females have skeletal abnormalities including kyphosis [23]. Conversely, in the presence of estrogen, FSH has been indicated to decrease bone mass directly via FSHR in osteoclasts [63]. That is supported by some clinical studies [64] and increased bone mass and decreased osteoclastic resorption in haploinsufficient $\mathrm{FSH} \beta+/-$ mice in comparison to $\mathrm{FSH} \beta+/+$ mice [63]. The bone metabolism in Ins2-hFSH+ and Ins2-hFSH +xhpg mice however demonstrate that FSH has, at least in mice, primarily anabolic effect on bone and that this effect is ovary-dependent and does not involve direct FSH actions on bone, or LH signalling either [65].

Abnormal gonadotropin function can lead to two different types of aberrations in adrenal glands. Firstly, gonadectomy and the concomitant increase in LH trigger adrenal hyperplasia and tumorigenesis in certain inbred mouse strains [66]. This is followed by increased proliferation of non-steroidogenic small spindle-shaped 'A cells' in the subcapsular adrenal cortex, and later on, by appearance of LH-responsive steroidogenic B cells that together construct disorganized tumorigenic adrenocortical architecture [66]. Ectopic upregulation of adrenal LHCGR, however, occurs in both tumorigenic and nontumorigenic strains of mice, their F2 crossbreeds and their backcrosses, thus implying that adrenal LH action is not the immediate cause of tumors, but rather a promoting factor. A linkage analysis has revealed that post-gonadectomy adrenal tumorigenesis is driven by a quantitative trait locus on chromosome 18 and modulated by another one on chromosome 8, neither of them harbouring Lhcgr [66]. Other types of histological changes are observed in the adrenal gland of female $L H \beta C T P+$ [67], UBC-hCG $\beta+$ [33] and $F s h r^{D 580 H_{+}}$ [18] mice. At the cortico-medullary junction, a distinct layer of foamy and multinuclear cells is seen, which resembles the layer existing in estrogen-rich $U B C$-Arom + male mice and the layer induced by chronic estrogen administration [68]. The estrogen-induced hyperplasia is accompanied by enhanced corticosterone synthesis and development of Cushing's syndrome in the $L H \beta C T P+$ mice [67].

An interesting hypothesis is that LH can increase the susceptibility to Alzheimer disease (AD) [69]. Circumstantial evidence includes the presence of LHCGR in several brain regions [70, 71], the ability of LH and hCG to cross the blood-brain barrier [71], elevated LH concentrations in $\mathrm{AD}$ sufferers [72, 73], the linkage of certain LHCGR variants with reduced risk of $\mathrm{AD}$ [74], and the ability of $\mathrm{LH}$ to alter amyloid precursor processing toward the amyloidogenic pathway in vitro [75]. The cross-breedings of Lhcgr knockout mice and $\mathrm{APPsw}^{+}$Alzheimer model mice expressing human amyloid precursor, convincingly support this hypothesis; in the absence of LH action, accumulation of amyloid- $\beta$ peptide $(A \beta)$ is reduced, astrogliosis eases, and the production of several neuroproteins is corrected [76]. Elevated LH levels may hence promote $A \beta$ accumulation and hasten $\mathrm{AD}$ progression and the cross-breedings of the two mouse strains may turn out to be useful when investigating $\mathrm{AD}$ pathogenesis. In addition, the abolition of FSH signalling leads to neurodegenerative changes due to the depletion of circulating estrogen. Forko females demonstrate several biochemical and morphological alterations in central and peripheral neurons [77].

\section{Conclusions}

Numerous abnormalities in the animal models with disrupted or enhanced gonadotropin action demonstrate the highly sensitive nature of the reproductive systems. Small changes in the circulatory gonadotropin concentration and timing of 
gonadotropin action may alter the functions of gonads, the ovary in particular, and more drastic alterations like the complete abolition of gonadotropin action or chronic and intensely enhanced action, leads to sub- or infertility. In humans, deficiency of gonadotropins or their receptors results in hypogonadotropic and hypergonadotropic hypogonadism, respectively, while constitutively active gonadotropin receptors and gonadotropin-producing pituitary tumors can cause enhanced and chronic gonadotropin stimulus. Gonadotropin levels are also raised notably during pregnancy and postmenopausal years exposing women for enhanced gonadotropin stimulus. Thus mouse models are able to elucidate the mechanisms between the initial genetic defect and the eventual phenotype and may also predict possible outcomes of similar defects in humans paving the way for improved diagnostic and therapeutic strategies for these conditions.

For female fertility it is crucial to maintain the primordial follicular pool and ensure a proper follicular development and ovulation. The gain-of-function mouse lines demonstrate how a modest increase in FSH action can enhance fertility, but how more excessive and chronic gonadotropin action, of both FSH and $\mathrm{LH}$, leads to accelerated loss of the primordial follicles, improper follicle development, enhanced ovarian hormone production, anovulation, and finally to disruption of the function of the hypothalamic-pituitary-gonadal axis. For males in turn it is fundamental to ensure proper development and function of the Leydig and Sertoli cells and to maintain undisrupted spermatogenesis, which functions are sensitive to lack of and excessive gonadotropin, mainly LH action.

The animal models have also proven valuable in the exploration of gonadotropin dependent biological systems outside of the gonads. They include developmental programming of the male hypothalamic-pituitary axis in mice and the linkage of the wnt/ $\beta$-catenin and LH pathways in the development of mammary carcinomas. There is a strong correlation between the intensity of chronic gonadotropin signalling and severity of the outcome. Therefore a varieties of models are needed to phenocopy and predict corresponding human syndromes. Although some of the mouse lines produce supra-physiological levels of gonadotropins, these may demonstrate the amplified effects of the consequences of long-lasting chronic gonadotropin stimulation.

Open Access This article is distributed under the terms of the Creative Commons Attribution Noncommercial License which permits any noncommercial use, distribution, and reproduction in any medium, provided the original author(s) and source are credited.

\section{References}

1. Kumar TR, Wang Y, Lu N, Matzuk MM. Follicle stimulating hormone is required for ovarian follicle maturation but not male fertility. Nat Genet. 1997;15(2):201-4. doi:10.1038/ng0297-201.
2. Dierich A, Sairam MR, Monaco L, Fimia GM, Gansmuller A, LeMeur $\mathrm{M}$, et al. Impairing follicle-stimulating hormone (FSH) signaling in vivo: targeted disruption of the FSH receptor leads to aberrant gametogenesis and hormonal imbalance. Proc Natl Acad Sci USA. 1998;95(23):13612-7.

3. Abel MH, Wootton AN, Wilkins V, Huhtaniemi I, Knight PG, Charlton HM. The effect of a null mutation in the folliclestimulating hormone receptor gene on mouse reproduction. Endocrinology. 2000;141(5):1795-803.

4. Ma X, Dong Y, Matzuk MM, Kumar TR. Targeted disruption of luteinizing hormone beta-subunit leads to hypogonadism, defects in gonadal steroidogenesis, and infertility. Proc Natl Acad Sci USA. 2004;101(49):17294-9. doi:10.1073/pnas.0404743101.

5. Zhang FP, Poutanen M, Wilbertz J, Huhtaniemi I. Normal prenatal but arrested postnatal sexual development of luteinizing hormone receptor knockout (LuRKO) mice. Mol Endocrinol. 2001;15(1):172-83.

6. Lei ZM, Mishra S, Zou W, Xu B, Foltz M, Li X, et al. Targeted disruption of luteinizing hormone/human chorionic gonadotropin receptor gene. Mol Endocrinol. 2001;15(1):184-200.

7. Themmen APN, Huhtaniemi IT. Mutations of gonadotropins and gonadotropin receptors: elucidating the physiology and pathophysiology of pituitary-gonadal function. Endocr Rev. 2000;21 (5):551-83.

8. Kumar TR. What have we learned about gonadotropin function from gonadotropin subunit and receptor knockout mice? Reproduction. 2005;130(3):293-302. doi:10.1530/rep.1.00660.

9. Tena-Sempere M. GPR54 and kisspeptin in reproduction. Hum Reprod Update. 2006;12(5):631-9. doi:10.1093/humupd/dml023.

10. Bouligand J, Ghervan C, Guiochon-Mantel A, Young J. Hypogonadotropic hypogonadism and GNRH1 mutations in mice and humans. Front Horm Res. 2010;39:111-20. doi:10.1159/ 000312697.

11. Lei L, Jin S, Mayo KE, Woodruff TK. The interactions between the stimulatory effect of follicle-stimulating hormone and the inhibitory effect of estrogen on mouse primordial folliculogenesis. Biol Reprod. 2010;82(1):13-22. doi:10.1095/biolreprod.109.077404.

12. Motta PM, Makabe S, Nottola SA. The ultrastructure of human reproduction. I. The natural history of the female germ cell: origin, migration and differentiation inside the developing ovary. Hum Reprod Update. 1997;3(3):281-95.

13. Roy SK, Albee L. Requirement for follicle-stimulating hormone action in the formation of primordial follicles during perinatal ovarian development in the hamster. Endocrinology. 2000;141 (12):4449-56.

14. Balla A, Danilovich N, Yang Y, Sairam MR. Dynamics of ovarian development in the FORKO immature mouse: structural and functional implications for ovarian reserve. Biol Reprod. 2003;69 (4):1281-93. doi:10.1095/biolreprod.103.015552.

15. Tingen C, Kim A, Woodruff TK. The primordial pool of follicles and nest breakdown in mammalian ovaries. Mol Hum Reprod. 2009;15(12):795-803. doi:10.1093/molehr/gap073.

16. Wang Y, Newton H, Spaliviero JA, Allan CM, Marshan B, Handelsman DJ, et al. Gonadotropin control of inhibin secretion and the relationship to follicle type and number in the hpg mouse. Biol Reprod. 2005;73(4):610-8. doi:10.1095/biolreprod.105.039602.

17. Flaws JA, Abbud R, Mann RJ, Nilson JH, Hirshfield AN. Chronically elevated luteinizing hormone depletes primordial follicles in the mouse ovary. Biol Reprod. 1997;57(5):1233-7.

18. Peltoketo H, Strauss L, Karjalainen R, Zhang M, Stamp GW, Segaloff DL, et al. Female mice expressing constitutively active mutants of FSH receptor present with a phenotype of premature follicle depletion and estrogen excess. Endocrinology. 2010;151 (4):1872-83. doi:10.1210/en.2009-0966.

19. Oktay K, Briggs D, Gosden RG. Ontogeny of follicle-stimulating hormone receptor gene expression in isolated human ovarian follicles. J Clin Endocrinol Metab. 1997;82(11):3748-51. 
20. O'Shaughnessy PJ, Dudley K, Rajapaksha WR. Expression of follicle stimulating hormone-receptor mRNA during gonadal development. Mol Cell Endocrinol. 1996;125(1-2):169-75.

21. Gelety TJ, Magoffin DA. Ontogeny of steroidogenic enzyme gene expression in ovarian theca-interstitial cells in the rat: regulation by a paracrine theca-differentiating factor prior to achieving luteinizing hormone responsiveness. Biol Reprod. 1997;56(4):938-45.

22. McTavish KJ, Jimenez M, Walters KA, Spaliviero J, Groome NP, Themmen AP, et al. Rising follicle-stimulating hormone levels with age accelerate female reproductive failure. Endocrinology. 2007;148(9):4432-9.

23. Danilovich N, Babu PS, Xing W, Gerdes M, Krishnamurthy H, Sairam MR. Estrogen deficiency, obesity, and skeletal abnormalities in follicle-stimulating hormone receptor knockout (FORKO) female mice. Endocrinology. 2000;141(11):4295-308.

24. Kumar TR, Palapattu G, Wang P, Woodruff TK, Boime I, Byrne $\mathrm{MC}$, et al. Transgenic models to study gonadotropin function: the role of follicle-stimulating hormone in gonadal growth and tumorigenesis. Mol Endocrinol. 1999;13(6):851-65.

25. McGee EA, Hsueh AJ. Initial and cyclic recruitment of ovarian follicles. Endocr Rev. 2000;21(2):200-14.

26. Visser JA, Themmen AP. Anti-Mullerian hormone and folliculogenesis. Mol Cell Endocrinol. 2005;234(1-2):81-6. doi:10.1016/j. mce.2004.09.008.

27. De Leener A, Montanelli L, Van Durme J, Chae H, Smits G, Vassart G, et al. Presence and absence of follicle-stimulating hormone receptor mutations provide some insights into spontaneous ovarian hyperstimulation syndrome physiopathology. J Clin Endocrinol Metab. 2006;91(2):555-62. doi:10.1210/jc.2005-1580.

28. Pakarainen T, Zhang FP, Nurmi L, Poutanen M, Huhtaniemi I. Knockout of luteinizing hormone receptor abolishes the effects of follicle-stimulating hormone on preovulatory maturation and ovulation of mouse graafian follicles. Mol Endocrinol. 2005;19 (10):2591-602.

29. Galway AB, Lapolt PS, Tsafriri A, Dargan CM, Boime I, Hsueh AJ. Recombinant follicle-stimulating hormone induces ovulation and tissue plasminogen activator expression in hypophysectomized rats. Endocrinology. 1990;127(6):3023-8.

30. Matzuk MM, DeMayo FJ, Hadsell LA, Kumar TR. Overexpression of human chorionic gonadotropin causes multiple reproductive defects in transgenic mice. Biol Reprod. 2003;69(1):338-46. doi:10.1095/biolreprod.102.013953.

31. Risma KA, Clay CM, Nett TM, Wagner T, Yun J, Nilson JH. Targeted overexpression of luteinizing hormone in transgenic mice leads to infertility, polycystic ovaries, and ovarian tumors. Proc Natl Acad Sci USA. 1995;92(5):1322-6.

32. Meehan TP, Harmon BG, Overcast ME, Yu KK, Camper SA, Puett $\mathrm{D}$, et al. Gonadal defects and hormonal alterations in transgenic mice expressing a single chain human chorionic gonadotropin-lutropin receptor complex. J Mol Endocrinol. 2005;34(2):489-503. doi:10.1677/jme.1.01669.

33. Rulli SB, Kuorelahti A, Karaer O, Pelliniemi LJ, Poutanen M, Huhtaniemi I. Reproductive disturbances, pituitary lactotrope adenomas, and mammary gland tumors in transgenic female mice producing high levels of human chorionic gonadotropin. Endocrinology. 2002;143(10):4084-95.

34. Risma KA, Hirshfield AN, Nilson JH. Elevated luteinizing hormone in prepubertal transgenic mice causes hyperandrogenemia, precocious puberty, and substantial ovarian pathology. Endocrinology. 1997;138(8):3540-7.

35. Huhtaniemi I. Are gonadotrophins tumorigenic - a critical review of clinical and experimental data. Mol Cell Endocrinol. 2010;329 (1-2):56-61. doi:10.1016/j.mce.2010.04.028.

36. Huhtaniemi I, Rulli S, Ahtiainen P, Poutanen M. Multiple sites of tumorigenesis in transgenic mice overproducing hCG. Mol Cell Endocrinol. 2005;234(1-2):117-26.
37. Mann RJ, Keri RA, Nilson JH. Consequences of elevated luteinizing hormone on diverse physiological systems: use of the LHbetaCTP transgenic mouse as a model of ovarian hyperstimulation-induced pathophysiology. Recent Prog Horm Res. 2003;58:343-75.

38. Mikola M, Kero J, Nilson JH, Keri RA, Poutanen M, Huhtaniemi I. High levels of luteinizing hormone analog stimulate gonadal and adrenal tumorigenesis in mice transgenic for the mouse inhibin-alpha-subunit promoter/Simian virus $40 \mathrm{~T}$-antigen fusion gene. Oncogene. 2003;22(21):3269-78.

39. Aravindakshan J, Chen XL, Sairam MR. Chronology and complexities of ovarian tumorigenesis in FORKO mice: age-dependent gene alterations and progressive dysregulation of Major Histocompatibility Complex (MHC) Class I and II profiles. Mol Cell Endocrinol. 2010;329(1-2):37-46. doi:10.1016/j.mce.2010.05.015.

40. Danilovich N, Roy I, Sairam MR. Ovarian pathology and high incidence of sex cord tumors in follitropin receptor knockout (FORKO) mice. Endocrinology. 2001;142(8):3673-84.

41. Radu A, Pichon C, Camparo P, Antoine M, Allory Y, Couvelard A, et al. Expression of follicle-stimulating hormone receptor in tumor blood vessels. N Engl J Med. 2010;363(17):1621-30. doi:10.1056/NEJMoa1001283.

42. Pakarainen T, Zhang FP, Makela S, Poutanen M, Huhtaniemi I. Testosterone replacement therapy induces spermatogenesis and partially restores fertility in luteinizing hormone receptor knockout mice. Endocrinology. 2005;146(2):596-606.

43. Rivero-Muller A, Chou YY, Ji I, Lajic S, Hanyaloglu AC, Jonas $\mathrm{K}$, et al. Rescue of defective $\mathrm{G}$ protein-coupled receptor function in vivo by intermolecular cooperation. Proc Natl Acad Sci USA. 2010;107(5):2319-24. doi:10.1073/pnas.0906695106.

44. Rulli SB, Ahtiainen P, Makela S, Toppari J, Poutanen M, Huhtaniemi I. Elevated steroidogenesis, defective reproductive organs, and infertility in transgenic male mice overexpressing human chorionic gonadotropin. Endocrinology. 2003;144 (11):4980-90. doi:10.1210/en.2003-0403.

45. Ahtiainen P, Rulli SB, Shariatmadari R, Pelliniemi LJ, Toppari J, Poutanen M, et al. Fetal but not adult Leydig cells are susceptible to adenoma formation in response to persistently high hCG level: a study on hCG overexpressing transgenic mice. Oncogene. 2005;24(49):7301-9.

46. Kumar TR, Varani S, Wreford NG, Telfer NM, de Kretser DM, Matzuk MM. Male reproductive phenotypes in double mutant mice lacking both FSHbeta and activin receptor IIA. Endocrinology. 2001;142(8):3512-8.

47. Wreford NG, Rajendra Kumar T, Matzuk MM, de Kretser DM. Analysis of the testicular phenotype of the follicle-stimulating hormone beta-subunit knockout and the activin type II receptor knockout mice by stereological analysis. Endocrinology. 2001;142 (7):2916-20.

48. Baker PJ, Pakarinen P, Huhtaniemi IT, Abel MH, Charlton HM, Kumar TR, et al. Failure of normal Leydig cell development in follicle-stimulating hormone (FSH) receptor-deficient mice, but not FSHbeta-deficient mice: role for constitutive FSH receptor activity. Endocrinology. 2003;144(1):138-45.

49. Krishnamurthy H, Danilovich N, Morales CR, Sairam MR. Qualitative and quantitative decline in spermatogenesis of the follicle-stimulating hormone receptor knockout (FORKO) mouse. Biol Reprod. 2000;62(5):1146-59.

50. Xing W, Krishnamurthy H, Sairam MR. Role of follitropin receptor signaling in nuclear protein transitions and chromatin condensation during spermatogenesis. Biochem Biophys Res Commun. 2003;312(3):697-701. doi:10.1016/j.bbrc.2003.10.177.

51. Allan CM, Haywood M, Swaraj S, Spaliviero J, Koch A, Jimenez $\mathrm{M}$, et al. A novel transgenic model to characterize the specific effects of follicle-stimulating hormone on gonadal physiology in the absence of luteinizing hormone actions. Endocrinology. 2001;142(6):2213-20. 
52. Allan CM, Garcia A, Spaliviero J, Zhang FP, Jimenez M, Huhtaniemi I, et al. Complete Sertoli cell proliferation induced by follicle-stimulating hormone (FSH) independently of luteinizing hormone activity: evidence from genetic models of isolated FSH action. Endocrinology. 2004;145(4):1587-93.

53. Rulli SB, Huhtaniemi I. What have gonadotrophin overexpressing transgenic mice taught us about gonadal function? Reproduction. 2005;130(3):283-91.

54. Mohammad HP, Abbud RA, Parlow AF, Lewin JS, Nilson JH. Targeted overexpression of luteinizing hormone causes ovarydependent functional adenomas restricted to cells of the Pit-1 lineage. Endocrinology. 2003;144(10):4626-36. doi:10.1210/en.2003-0357.

55. Ahtiainen P, Sharp V, Rulli SB, Rivero-Muller A, Mamaeva V, Roytta M, et al. Enhanced LH action in transgenic female mice expressing hCGbeta-subunit induces pituitary prolactinomas; the role of high progesterone levels. Endocr Relat Cancer. 2010;17 (3):611-21. doi:10.1677/ERC-10-0016.

56. Gonzalez B, Ratner LD, Di Giorgio NP, Poutanen M, Huhtaniemi IT, Calandra RS, et al. Endogenously elevated androgens alter the developmental programming of the hypothalamic-pituitary axis in male mice. Mol Cell Endocrinol. 2011;332(1-2):78-87. doi:10.1016/j.mce.2010.09.016.

57. Narayan P, Gray J, Puett D. Yoked complexes of human choriogonadotropin and the lutropin receptor: evidence that monomeric individual subunits are inactive. Mol Endocrinol. 2002;16(12):2733-45.

58. Abbud RA, Ameduri RK, Rao JS, Nett TM, Nilson JH. Chronic hypersecretion of luteinizing hormone in transgenic mice selectively alters responsiveness of the alpha-subunit gene to gonadotropin-releasing hormone and estrogens. Mol Endocrinol. 1999;13(9):1449-59.

59. Heaney AP, Fernando M, Melmed S. Functional role of estrogen in pituitary tumor pathogenesis. J Clin Invest. 2002;109(2):27783. doi:10.1172/JCI14264.

60. Fedele M, Visone R, De Martino I, Troncone G, Palmieri D, Battista $\mathrm{S}$, et al. HMGA2 induces pituitary tumorigenesis by enhancing E2F1 activity. Cancer Cell. 2006;9(6):459-71. doi:10.1016/j.ccr.2006.04.024.

61. Milliken EL, Ameduri RK, Landis MD, Behrooz A, Abdul-Karim FW, Keri RA. Ovarian hyperstimulation by LH leads to mammary gland hyperplasia and cancer predisposition in transgenic mice. Endocrinology. 2002;143(9):3671-80.

62. Kuorelahti A, Rulli S, Huhtaniemi I, Poutanen M. Human chorionic gonadotropin (hCG) up-regulates wnt5b and wnt7b in the mammary gland, and hCGbeta transgenic female mice present with mammary Gland tumors exhibiting characteristics of the Wnt/beta-catenin pathway activation. Endocrinology. 2007;148 (8):3694-703. doi:10.1210/en.2007-0249.

63. Sun L, Peng Y, Sharrow AC, Iqbal J, Zhang Z, Papachristou DJ, et al. FSH directly regulates bone mass. Cell. 2006;125(2):247-60. doi:10.1016/j.cell.2006.01.051.

64. Iqbal J, Sun L, Zaidi M. Commentary-FSH and bone 2010: evolving evidence. Eur J Endocrinol. 2010;163(1):173-6. doi:10.1530/EJE-10-0397.

65. Allan CM, Kalak R, Dunstan CR, McTavish KJ, Zhou H, Handelsman DJ, et al. Follicle-stimulating hormone increases bone mass in female mice. Proc Natl Acad Sci USA. 2010;107 (52):22629-34. doi:10.1073/pnas.1012141108.

66. Bernichtein S, Petretto E, Jamieson S, Goel A, Aitman TJ, Mangion JM, et al. Adrenal gland tumorigenesis after gonadectomy in mice is a complex genetic trait driven by epistatic loci. Endocrinology. 2008;149(2):651-61. doi:10.1210/en.2007-0925.

67. Kero J, Poutanen M, Zhang FP, Rahman N, McNicol AM, Nilson $\mathrm{JH}$, et al. Elevated luteinizing hormone induces expression of its receptor and promotes steroidogenesis in the adrenal cortex. J Clin Invest. 2000;105(5):633-41. doi:10.1172/JCI7716.
68. Bernichtein S, Peltoketo H, Huhtaniemi I. Adrenal hyperplasia and tumours in mice in connection with aberrant pituitary-gonadal function. Mol Cell Endocrinol. 2009;300(1-2):164-8. doi:10.1016/j.mce.2008.10.005.

69. Barron AM, Verdile G, Martins RN. The role of gonadotropins in Alzheimer's disease: potential neurodegenerative mechanisms. Endocr. 2006;29(2):257-69. doi:10.1385/ENDO:29:2:257.

70. Lei ZM, Rao CV, Kornyei JL, Licht P, Hiatt ES. Novel expression of human chorionic gonadotropin/luteinizing hormone receptor gene in brain. Endocrinology. 1993;132(5):2262-70.

71. Lei ZM, Rao CV. Neural actions of luteinizing hormone and human chorionic gonadotropin. Semin Reprod Med. 2001;19 (1):103-9. doi:10.1055/s-2001-13917.

72. Bowen RL, Isley JP, Atkinson RL. An association of elevated serum gonadotropin concentrations and Alzheimer disease? J Neuroendocrinol. 2000;12(4):351-4. doi:jne461.

73. Short RA, Bowen RL, O'Brien PC, Graff-Radford NR. Elevated gonadotropin levels in patients with Alzheimer disease. Mayo Clin Proc. 2001;76(9):906-9.

74. Haasl RJ, Ahmadi MR, Meethal SV, Gleason CE, Johnson SC, Asthana S, et al. A luteinizing hormone receptor intronic variant is significantly associated with decreased risk of Alzheimer's disease in males carrying an apolipoprotein E epsilon4 allele. BMC Med Genet. 2008;9:37. doi:10.1186/1471-2350-9-37.

75. Bowen RL, Verdile G, Liu T, Parlow AF, Perry G, Smith MA, et al. Luteinizing hormone, a reproductive regulator that modulates the processing of amyloid-beta precursor protein and amyloid-beta deposition. J Biol Chem. 2004;279(19):20539-45. doi:10.1074/ jbc.M311993200.

76. Lin J, Li X, Yuan F, Lin L, Cook CL, Rao ChV, et al. Genetic ablation of luteinizing hormone receptor improves the amyloid pathology in a mouse model of Alzheimer disease. J Neuropathol Exp Neurol. 2010;69(3):253-61. doi:10.1097/NEN.0b013e3181d072cf.

77. Tam J, Danilovich N, Nilsson K, Sairam MR, Maysinger D. Chronic estrogen deficiency leads to molecular aberrations related to neurodegenerative changes in follitropin receptor knockout female mice. Neuroscience. 2002;114(2):493-506. doi: S0306452202002786.

78. Zhang FP, Pakarainen T, Poutanen M, Toppari J, Huhtaniemi I. The low gonadotropin-independent constitutive production of testicular testosterone is sufficient to maintain spermatogenesis. Proc Natl Acad Sci USA. 2003;100(23):13692-7. doi:10.1073/ pnas. 2232815100 .

79. d'Anglemont de Tassigny X, Fagg LA, Dixon JP, Day K, Leitch HG, Hendrick AG, et al. Hypogonadotropic hypogonadism in mice lacking a functional Kiss1 gene. Proc Natl Acad Sci USA. 2007;104(25):10714-9. doi:10.1073/pnas.0704114104.

80. Seminara SB, Messager S, Chatzidaki EE, Thresher RR, Acierno Jr JS, Shagoury JK, et al. The GPR54 gene as a regulator of puberty. N Engl J Med. 2003;349(17):1614-27. doi:10.1056/ NEJMoa035322.

81. Funes S, Hedrick JA, Vassileva G, Markowitz L, Abbondanzo S, Golovko A, et al. The KiSS-1 receptor GPR54 is essential for the development of the murine reproductive system. Biochem Biophys Res Commun. 2003;312(4):1357-63. doi:S0006291X03024070.

82. Cattanach BM, Iddon CA, Charlton HM, Chiappa SA, Fink G. Gonadotrophin-releasing hormone deficiency in a mutant mouse with hypogonadism. Nature. 1977;269(5626):338-40.

83. Pask AJ, Kanasaki H, Kaiser UB, Conn PM, Janovick JA, Stockton DW, et al. A novel mouse model of hypogonadotrophic hypogonadism: N-ethyl-N-nitrosourea-induced gonadotropinreleasing hormone receptor gene mutation. Mol Endocrinol. 2005;19(4):972-81. doi:10.1210/me.2004-0192.

84. Wu S, Wilson MD, Busby ER, Isaac ER, Sherwood NM. Disruption of the single copy gonadotropin-releasing hormone 
receptor in mice by gene trap: severe reduction of reproductive organs and functions in developing and adult mice. Endocrinology. 2010;151(3):1142-52. doi:10.1210/en.2009-0598.

85. Allan CM, Wang Y, Jimenez M, Marshan B, Spaliviero J, Illingworth $\mathrm{P}$, et al. Follicle-stimulating hormone increases primordial follicle reserve in mature female hypogonadal mice. J Endocrinol. 2006;188(3):549-57. doi:10.1677/joe.1.06614.

86. Haywood M, Tymchenko N, Spaliviero J, Koch A, Jimenez M, Gromoll J, et al. An activated human follicle-stimulating hormone $(\mathrm{FSH})$ receptor stimulates FSH-like activity in gonadotropin-deficient transgenic mice. Mol Endocrinol. 2002;16(11):2582-91.

87. Allan CM, Lim P, Robson M, Spaliviero J, Handelsman DJ. Transgenic mutant D567G but not wild-type human FSH receptor overexpression provides FSH-independent and promiscuous glycoprotein hormone Sertoli cell signaling. Am J Physiol Endocrinol Metab. 2009;296(5):E1022-8. doi:10.1152/ ajpendo.90941.2008. 